Article

\title{
Towards a Common Public Culture? Boundaries to Belonging in Catalonia
}

\author{
Angelina Sánchez-Martí ${ }^{1, *}$, Jordi Pàmies ${ }^{2}$, Alejandro Caravaca ${ }^{2}$, and Berta Llos $^{2}$ \\ ${ }^{1}$ Department of Applied Pedagogy, Autonomous University of Barcelona, Spain \\ 2 Department of Educational Theories and Social Pedagogy, Autonomous University of Barcelona, Spain \\ * Corresponding author (angelina.sanchez@uab.cat)
}

Submitted: 14 October 2021 | Accepted: 4 January 2022 | Published: 20 April 2022

\begin{abstract}
The tension between the will to build a collective national identity and the increasing diversity of today's societies is one of the main challenges facing nation-states today. Catalan society, being no exception, also faces many challenges as diasporic identities and transnational loyalties proliferate, weakening both citizens' roots and their need to belong. The present article aims to identify situations and social spaces of discrimination and explicit/implicit racism, existing mechanisms and responses aimed at avoiding and dealing with these situations, and the groups they affect most in Catalan society. Through a participatory research, 23 focus groups were carried out - of between six and 12 participants - in eight territories (Pàmies et al., 2020). Results reveal diverse areas of discrimination, ranging from the violation of civil and political rights to that of economic, social, and cultural rights. The situations described and named by some as examples of micro-racism complicate the sense of belonging for many citizens, challenging the real possibility of achieving a pluricultural collective identity. Thus, to promote belonging and build a common public culture with which everyone feels identified, as promoted by official speeches, it is necessary to recognize plurality and diversity and promote citizen participation-and representation-in devising public actions, as well as encourage interactions that emphasize all common and shared aspects in a context conditioned by the reactive fragmentation of identity politics.
\end{abstract}

\section{Keywords}

Catalan identity; Catalonia; collective identity; diversity; pluricultural identity; sense of belonging

\section{Issue}

This article is part of the issue "Promoting Social Inclusive Experiences in Uncertain Times" edited by Ana Belén Cano-Hila (University of Barcelona).

(C) 2022 by the author(s); licensee Cogitatio (Lisbon, Portugal). This article is licensed under a Creative Commons Attribution 4.0 International License (CC BY).

\section{Introduction}

Societies today are, by definition, multicultural, complex, and diverse. Catalonia is no exception to this, and although the entire region does not fulfil the description of superdiversity (Phillimore et al., 2020; Vertovec, 2007), it is a place where people of diverse origins, social classes, religions, genders, ages, sexual orientations, and more live together. Indeed, Catalan society faces many challenges as diasporic identities and transnational loyalties proliferate, weakening both citizens' roots and their need to belong. It is also undeniable that the increase in migratory processes (Bernad \& Llevot, 2018) has accelerated certain changes towards multiculturalism (Martínez-Ariño et al., 2011), polyethnicity, and multina- tionalism (Kymlicka, 1995), while social inequalities have been accentuated (del Griera, 2016).

All of these relatively new situations facing diversity -in its broadest possible meaning (Todd, 2011) - have forced nation-states to consider how they can successfully build civic communities that incorporate the heterogeneous values, ideals, and goals of all their citizens (Banks, 2007; Moodod, 2010). The tension between the desire to build a collective national identity and the reality of the diversity of their citizens is one of the main challenges facing nation-states in a highly globalized and interconnected context today (Banks, 2008; Moodod, 2021a). The "state" is understood here as the administrative apparatus through which the government answers to its responsibilities. For this reason, although 
in the case of Catalonia it is, in many ways, a conflicting term, it can be directly or indirectly extrapolated to the region-our context of analysis.

For years, Catalonia, as well as Spain, has been characterized by fairly tolerant policies and attitudes toward migrants (Burchianti \& Zapata-Barrero, 2014). However, as is the case throughout the European landscape, the increasing presence of far-right movements in the region is beginning to shake its 37 years of social-democratic rule, overlapping with other political processes of enormous significance such as the Catalan independence movement (Bernat \& Whyte, 2019) or the feminist protest cycle that has turned feminism into one of the main vectors of politicization in Spain (Cabezas, 2022). These ongoing issues represent Spain's worst political crisis in 40 years and their effects loom over the political and social milieu in both Catalonia and Spain today, generating social fractures among their citizens (Byrne, 2021). Caught in the middle of this, in its 2017-2020 Citizenship and Migration Plan (Regional Government of Catalonia, 2017), Catalonia defined its firm will to implement an intercultural model to advance towards the construction of a "common public culture," with which all people living in the region can feel identified. However, this model has not been exempt from exclusionary dynamics and experiences of exclusion and violence, which have been repeatedly experienced by immigrant families and their children (Carrasco et al., 2011).

In Catalonia, but also globally, both diversity management policies and research carried out from the field of social sciences have focused mainly on the integration of migrant people and their children either by engaging host societies as well as migrants (two-way integration) or by acknowledging that the role played by the country of origin (three-way integration; see European Commission, 2020; Garcés \& Penninx, 2016). These perspectives, which on too many occasions seems to reduce all the diversity of the territory to migrants and their families, have generated different dynamics and challenges to the critical dialogue that should elucidate us on the cultural dynamics of all citizens in Catalonia and their contribution to Catalan society.

Thus, there is an urgent need for research on the binomial of integration and sense of belonging due to the multiple tensions and hostility that have been installed in the territory, arising from reactions to identities and differences at both the local and global levels. This article wishes to contribute to the literature in this direction. Specifically, we investigate some of the situations of exclusion and violence that represent limiting factors to the development of a sense of belonging in Catalan territory. This development entails building a common public culture that includes all the diversities present within the framework of an intercultural model. This is aligned with European efforts and interest in managing diversity and making social cohesion feasible. The present article is closely linked with previous work developed by Yuval-Davis (2006) and Anthias (2009) about the pro- cesses of collective identification, which have overemphasized ethnic issues. However, these processes also form and prevail through other social categories, such as gender, age or life cycle, social class, political beliefs, and values (Narciso, 2021).

In the following sections, we analyse the diversity management model defined in Catalonia as well as other key ideas regarding the relationship between the construction of a common public culture, a collective identity, and a sense of belonging. We then expose the methodology employed throughout our research and discuss our main results following the report Towards a Pluricultural Collective Identity (Pàmies et al., 2020) commissioned by the School of Public Administration of Catalonia and the Secretariat for Equality, Migration and Citizenship (SIMC). Finally, the last section of our article presents the conclusions and limitations of the intercultural model in Catalonia, considering the axes of discrimination and the structural factors of oppression identified in the research.

\subsection{The Diversity Management Model in Catalonia: Towards a Common Public Culture}

Catalonia does not have full competence over migration issues, which has a direct link with how diversity is managed. Much of this competence rests with the Spanish central government. Despite this fact, the will of the Catalan government has been to fully manage migration issues, as evidenced by the signing of the National Pact for Immigration in 2008 (Regional Government of Catalonia, 2008). The agreement does not clearly specify Catalonia's position regarding diversity management, although the term "intercultural" appears five times in various sections of the document. The explicit desire to move towards an intercultural model has been reflected in other official documents as well, such as the 2017-2020 Citizenship and Migration Plan (Regional Government of Catalonia, 2017, pp. 18-19):

Our aim is to address the diversity of Catalan society from the perspective of interculturalism, a perspective that seeks to put the ideas and actions of every person or group with specific cultural identities on an equal footing. From this perspective, dialogue, consensus, integration, and coexistence between these diverse cultures are favoured. From this perspective, the reality of conflicts is not denied, but rather their resolution is sought through knowledge, proximity, reconciliation and the search for shared common denominators. This process is building a Catalan public culture and a social ethic that helps us advance in the construction of a democratic, integrated and cohesive society.

However, we must not forget that dynamics referring to cultural diversity, and how these are managed by governments, must be viewed from a historical perspective 
in a specific social and political context-or within a discourse, in Foucauldian terms. It is important to bear in mind that said context conditions the implementation of any plan-or "policy as text" (Ball, 1993)-as does its interpretation by the agents who execute it-related to the concept of "policy enactment" (Ball et al., 2012). Given the above, as Shaimi (2018) denounced, differences exist between the discursive and the practical levels. According to him, in practice, the majority perspective contemplates a homogenization of heterogeneity, and conceives autochthonous culture as unitary, relegating "diversity" to migrant people, even if the Catalan model is explicitly labelled as being intercultural. In addition, he states that discriminations preventing the exercise of the rights of freedom and equality, under what he describes as a "culturalization of politics," are not taken into account. In similar terms, Rubio-Carbonero and Zapata-Barrero (2017) point out that there is an implicit discriminatory tendency in the nationalist political discourse that prioritises own identity, culture, and nation. Consequently, the common public culture is not built on a neutral basis of real equality; rather there are structural conditioning factors and social dynamics that limit its construction. These will be our object of study in this article.

There would appear to be a close link between common public culture and the sphere of identity and belonging, and more specifically the construction of collective identities-similar to the concept of citizenship posited by Koopmans et al. (2005). However, these collective identities built on the basis of legal nationality present challenges and limitations related to aspects such as the current context of globalization, the potential homogenization of culture, the progressive disappearance of symbolic and physical borders (Benhabib, 2006; Gangahar, 2015; Pries, 2013), the trend towards increasingly diverse and plural societies (Kymlicka, 1995; Martínez-Ariño et al., 2011), and the plurality of people's identities and their multidimensional nature-that is, multiculturalism (Lapresta \& Huguet, 2008; Moodod, 2021b). In fact, nationalism is based on the need to defend national culture, tradition, identity, language, and values, and this promotion of one own's identity has historically defined itself against other nations, races, and ethnicities (Rubio-Carbonero \& Zapata-Barrero, 2017).

Therefore, although the sense of belonging to a territory can be developed in different ways, it is always a dynamic process that is socially constructed and intimately linked to power relations (Álvarez-Gálvez et al., 2018; Benhabib, 2006; Giesen \& Seyfert, 2016; Pàmies et al., 2020). Such is the case of Spain and, by extension, Catalonia. The articulation of collective feelings of national belonging has been one of its backbones as well as in other countries. This articulation has occurred mainly through nationality, that is, legal recognition as a member of a specific socio-political community normatively regulated by codes that recognize certain free- doms and responsibilities. The state has been articulated as an instrument for the protection of the nation, configured as a collective identity to which all the people who form it belong. Thus, nationality policies have served to define a legally constructed "we" in opposition to a differing "they." In this sense, the role of diversity management policies and the administrative model adopted-whether assimilationist, multicultural, intercultural, etc.- - have a strong impact on how identity and belonging processes are constructed, and consequently on the shared public culture sought in said policies.

\section{Method}

This article is part of a participatory research designed to answer the question: How can we promote the construction of a pluricultural collective identity based on public policies in Catalonia? We aimed to identify the potentialities, tensions, and limits of a collective identity-and, more specifically, to identify the situations and social spaces of discrimination and explicit/implicit racism, existing mechanisms and responses aimed at avoiding and dealing with these situations, and the groups most affected by them in Catalonia.

\subsection{Data Collection and Participants}

Twenty-three (23) focus groups were carried out, according to their inherent participatory nature, based on group processes (Farinosi et al., 2019). The focus groups-of between six and 12 participants-were held in eight territories of Catalonia, with a balanced participation of 173 people: Barcelona city (12.9\%), Vic-Manlleu $(16.2 \%)$, Olot $(11.6 \%)$, Baix Penedès $(13.9 \%)$, Alcarràs (13.9\%), Premià de Mar (10.4\%), Santa Coloma de Gramenet (9.8\%), and Ripoll (11.6\%). These territories were chosen based on the maximum possible variability and four inclusion criteria: (a) percentage and (b) origin of the migrated population, (c) size of the municipality, and its (d) location within Catalonia.

In choosing the territories and participants, we counted on the support of the SIMC and the participation of local decision-makers who were familiar with the contexts and acted as mediators. Their predisposition and support were key in forming the groups. Three focus groups were held in each territory with: (a) young people and young adults (28.3\%); (b) decision-makers from the local and regional governments (42.2\%); and (c) representatives of the associations and citizens in general (29.5\%). Santa Coloma was the only territory where a focus group with representatives of the associations and citizens could not be held. Participation was higher in the case of women (65.3\% of the decision-makers and $60.8 \%$ of the representatives of associations were women), except in the focus group of young people (44.9\%). Most non-EU participants were found among the groups of entities (47.1\%) and young people (30.6\%). Only $12.3 \%$ of the participants in the local decision-maker groups 
were born outside the EU. Regarding the place of birth, most of the participants were born in Catalonia (63.6\%) and among those born outside of Spain, the highest proportion were born in Morocco (13.9\%). 6.4\% were born in other parts of Spain, $5.2 \%$ in other African countries, $5.2 \%$ in countries of South and Central America, $2.3 \%$ in other EU countries, $1.7 \%$ in countries of Western Asia, and $1.7 \%$ in countries of South Asia. Of the 173 participants, more than half (71.8\%) had higher studies, $18.2 \%$ had post-compulsory education or vocational studies, and only $10 \%$ had compulsory education.

The focus groups followed a semi-structured script with the main aim of involving all participants in a conversation about "pluricultural identity." The participatory dynamics consisted of three different sections: First, based on a projective technique using Gianni Rodari's story Chi Sono Io?, an introspective brainstorming activity was conducted about identity and experiences around it using emic labels. Then, participants engaged in a situated reflection on the concepts of individual and collective identity, before finally exploring different facilitating and limiting factors in the construction of a pluricultural collective identity, discussing the ideal and real role of policies in fostering this.

A previous step taken in this study to prepare the focus group strategy was to hold a meeting with the entire research team to discuss our positionalities and go beyond self-reflexivity. We put into practice the participatory dynamics designed to raise awareness and provoke reflection based on our individual and collective identities and as socially and culturally specific subjects. This also allowed us to create time and a space to engage in critical views while remaining open to disagreement. It is important to note that the team was made up of researchers from various universities, as well as public policy consultants, decision-makers, and researchers from civil society.

\subsection{Data Analysis}

The focus groups were recorded and later transcribed, and the transcription was then deductively and inductively content analysed with the support of the CADQAS NVivo 12 software. To analyse the findings in greater depth, the following progressive levels of reduction and theoretical structuring of the information were followed:

(a) creation of a filing system for the collected data; (b) segmentation, identification, and grouping of units of meaning into initial descriptive categories, initially defined deductively; (c) segmentation and identification of analytical units of meaning from which-based on the discovery, encoding and interpretation of all data(d) an overall model finally emerged. It is precisely at this last analytical level that Braun and Clarke (2006) state the content analysis begins, which gives rise to the emergence of the main categories from triangulation, fundamentally based on the constant comparative method. The research process followed embraces the Autonomous University of Barcelona's code of good research practices. In addition, throughout the process, the research team took into consideration the six key axes proposed by the European Commission for a project to be aligned with responsible research and innovation principles, ensuring compliance with the dimensions of citizen participation, gender equality, science education, open access, ethics, and governance.

\section{Results}

The results section has been divided into the main fields of discrimination identified by participants: (a) labour market and housing; (b) social institutions and public administration; and (c) education.

\subsection{Discrimination in the Fields of Labour Market and Housing: Access and Conditions}

Two of the fields of discrimination identified are related to access to the labour market and housing. First, participants in all the focus groups agreed that explicit racism occurs in job recruitment processes in Catalonia, based on the alleged origin and/or physical appearance of applicants. In fact, this was identified as a widespread phenomenon in the labour market in general, but most especially in those private sectors with little to no effective regulation in terms of recruitment criteria-that is, little control of non-discriminatory processes. Regarding this, one employee at a public occupation service stated:

Companies tell you: "We don't want Moroccans." Like this: "We don't want Moroccans!" As an employee at a public institution, I must send them all the applications, but it's the companies who end up choosing. (associations, FG2)

The above intervention illustrates a very common topic in the focus groups: In Catalonia, the business sector often shares this pejorative view towards migrant people-or racialized people in general regardless of their migration background-which excludes them from certain work positions, especially when these positions involve direct contact with customers:

I remember that one day I was with a Moroccan guy, and he asked me: "Why here in this city don't we see migrant people working directly with the public?" He asked it clearly. And the truth is that most people don't want migrant people, especially sub-Saharan people, dealing with customers face-to-face. (associations, FG3)

This situation creates an image that young people interiorize even when they are still in the compulsory stages of the school system, thus conditioning their future aspirations and pathways. In this regard, a worker in the non-governmental sector revealed both a perceived-as- 
foreigner teenager's low future perspectives of access to the labour market and his interiorization of the marginalized position he occupies at school in terms of academic (in)capacity:

A 12-year-old boy told me: "I know I'm not good at studying, I've already been told. When I turn 16, what can I expect? What can I expect here in this city?" And you need to be sincere and tell him: "If society has advanced enough and you go to a bar and they have a CV of someone called Marc or Manel [used as (stereo)typical traditional Catalan names] and another CV of someone called Mohammed, and they choose you....I'd love to tell you that they'd choose you, Mohammed, because you're worth so much, but I'm afraid they wouldn't." Of course it's prejudice, and I hope I'm wrong, but this is still happening here in this city. (associations, FG3)

The possibility of obtaining a job seems to increase only when the perceived-as-foreigner individual accumulates the necessary social capital, has good references or even a direct recommendation from a local personsomething that is not required for those people not perceived as foreigners. In the same vein, the following quote illustrates the racist discourse of the speaker when she recognizes that, unless she has extraordinary information, she will first hire a local white person:

They'll hire Mohammed [used as a (stereo)typical non-traditional Catalan name] if Mohammed has good references from people you know. One day this black guy came to me and told me: "This guy works with me and he's a very good person." So, I said: "Perfect, I don't mind hiring him." But if you see two random CVs, you think at first: "I'll chose the easiest option, the local, the white guy." (associations, FG3)

This last quote, which was followed by a discussion within the focus group, evinces the complexity of views and experiences from participants. Far from having a monolithic discourse, the participants manifested differential nuances, contradictions, and even conflicts. Still, the degree of consensus within and between most focus groups was remarkable.

Moving beyond difficulties regarding access to also consider working conditions, the following quote provides a good example of a common reality in different areas of Catalonia, especially in those where agriculture represents one of the main economic sectors. Not having the official documents-which might itself become a limiting factor in developing a feeling of belonging to a certain territory, for most rights to citizenship are then neglected-is used by some owners of agricultural businesses to enforce exploitative working conditions:

Regarding working conditions, it's all the same, I go to workers' settlements and I see...I am told cer- tain things...I feel embarrassed. "You don't have official documents? Great, I'll hire you, but I'll only pay three euros per hour." So, owners are committing two offences: First, they hire the workers without a contract and without access to the social security system, and, second, workers are paid less than the minimum wage. (associations, FG9)

Along with the labour market, another space where discrimination was identified is access to housing. This topic also emerged in most territories, especially in the associations and the young people focus groups. Firstly, there is an explicit discourse on the part of homeowners regarding not being willing to rent houses or apartments to individuals perceived as foreigners, consequently denying them the right to housing. Secondly, abuse of power was also identified concerning housing conditions, in those cases where access is achieved. Some workers in the non-governmental sector evidenced this in the following quotes:

I went to a real estate agency and said: "We need some apartments." And they replied: "We have a problem, because homeowners don't want to rent their apartment to black people, Moors, or Romanians." And I flipped out....Others accept renting [out] to them, but when you go to visit the apartment with the clients, you get embarrassed because of the very high prices....Some house owners take advantage of people's vulnerability. (associations, FG12)

We have big problems with people who have a permanent job and enough income to rent an apartment...but we can't offer them an apartment, even though some are empty, because house owners don't want to. (associations, FG3)

This situation, in which house owners explicitly order real estate agencies not to rent their apartments or houses to certain people represents a clear violation of their rights under an evident racist or xenophobic discoursedespite the Catalan and Spanish legal frameworks prohibiting such discriminatory criteria. As the literature points out (e.g., Álvarez-Gálvez et al., 2018; Benhabib, 2006; Giesen \& Seyfert, 2016; Pàmies et al., 2020), these situations of discrimination related to housing and the labour market might difficult the creation of a common sense of belonging-which is socially constructed-for they imply power relations with strong consequences for certain people. All this can be illustrated in the following quote:

There is inequality regarding access to the labour market, and there is more unemployment depending on your origin: This naturally doesn't facilitate your feeling part of a community, being discriminated against workwise. (young person, FG5) 


\subsection{Discrimination at the Institutional Level: Administration, Police, and Political Parties}

A second field that has been identified is related to institutional discrimination - that is, the discrimination produced by institutional structures, and, by extension, undertaken by actors from public institutionsexperienced by marginalized people or groups because of their origin, nationality, or physical appearance. The situations identified arise, first, due to legislation and the public administration, through the actions of the state security forces, and in situations experienced in the daily life of politics.

Firstly, the dynamics of the administration itself are identified as a field of discrimination. A violation of social and political rights was mentioned in most groups (e.g., people who have settled in a municipality not being able to exercise their right to vote). As one participant stated: "We must think in terms of citizenship and political rights if we want to promote pluricultural collective identities." However, the following quote illustrates how the "foreign affairs" competencies of the state have been delimited over time and how this is a limiting factor when it comes to achieving a sense of belonging:

We [migrant people] first depended on the Ministry of the Interior, 10,12, 15 years ago, "because we were criminals"; now, we depend on the Ministry of Labour, "because we are workers." Until there is a Ministry of Citizenship or something that involves people just for the sake of living here, of migrating here....we are categorized, and this label has impacts on you. (associations, FG6)

There was a strong consensus among participants in all the territories regarding the restrictive nature of the current legal framework to achieve civil and political rights. In addition to that, they also agreed on difficulties regarding access to public service, which reduces the presence of people from different origins in those services:

It's true that the legal framework is totally against us....This has many limiting consequences on [migrant] flows, irregularity...it prevents you [from feeling a sense of belonging]....For instance, regarding family reunification procedures, people must wait 10 [to] 15 years to be able to reunite with their family. (administration, FG7)

This unjust situation is reproduced in the behaviour of the security forces-as emerged especially in most young people focus groups. In general, their discriminatory activities are also part of the everyday micro-racism to which young people, the children of migrants, are especially exposed.

My sister, my mother, my little brother, and I were at Barcelona airport. My sister wasn't with us, she was in the car waiting for us with her husband, and the police officers stopped her because they saw my sister with my mother, who was wearing a hijab, and they asked for our passports.....After that, they asked me for my ID card, which my mother has, and they also asked us for our passports, they asked us how old my little brother was, they asked him what his name was, if he was happy....And I didn't understand why they did that....Why that obsession with asking migrants questions? (young person, FG2)

Through the narration of a young woman's experience with her family in the last quote-which constitutes just one example of the many experiences that emerged about racism in the police-the arbitrariness associated with prejudice is pointed out. In other words, police officers tend to have more suspicions about people perceived as foreigners not behaving in a "civilized way," to the point of often questioning their legal status. These situations occur constantly, as the participants stated, and especially, although not only, among young people:

I took the bus with my daughter and there were two police officers standing at the bus entrance and asking for our passports. My friend said: "Are you asking me for my passport? It's because I'm black, right? In fact, I was born here, and I haven't done anything. Tell me what I have done." She confronted him and the other [police officer] got embarrassed. In the end, she gave him [the passport], but not without yelling at the police officer first. (young person, FG2)

In the field of politics, as stated especially in two territories, the increasing presence of hate speech from the far right, but also less explicitly from other parties, fosters the feeling of certain marginalized groups being excluded from the common public culture. These groups become a focus of attack because the far-right makes them responsible for the faults in the system. In this regard, a young woman explained an experience in her town, where she was heckled on social networks:

We went to a demonstration with a sign that one of my colleagues had made, that said: "Feminism will be anti-racist or won't be." And the people from the local radio asked us for a photo; lots of people asked us for photos with the sign. And then the photo was posted, and we appeared there, in that and other photos. Well, so the Vox political leader posted the photo on his Facebook saying: "Look at what I found....What represents us in this city." And he let his followers comment with discrimination and hate comments...."They should go and defend their feminism in their country...fucking Blacks, but what are they doing here? If I caught them"....And I think they said they would kill us or something....Well, a lot of things, and we couldn't report it either. (young person, FG2) 
The discourse here illustrates the explicit racism of a specific political leader, but, at the same time, it evidences the position of some citizens and their adherence to discriminatory and racist comments that mark the limits of otherness and the boundaries of "us" and "them," especially against certain groups (Carrasco et al., 2011).

\subsection{Discrimination in the Field of Education: Teachers and Families}

Several discriminatory episodes were identified in the field of education, mostly by young people from a migrant background, but also by educators and other education-related workers participating in the focus groups, with a high degree of consensus between territories. The educators pointed out problems related to segregation across schools, whereas the young participants highlighted segregation within the schools. In other words, these young people identified the fact that some teachers had lower expectations of them, and that they were mostly placed in the lowest groups in those schools with allegedly based-on-ability, homogenous grouping practices-which, as has been stated in international research, has a negative effect on the students in question. Above and beyond this, however, discrimination experiences also reach their families: Despite there being extensive literature that refutes it (El Mouali, 2021; Leiva, 2011), some mothers from a migrant background are considered less capable and even less interested in their children's education-as stated in two territories:

At the school, we also find that families' associations constantly criminalize women, who, of course, don't attend the meetings because they don't understand the teachers. So, there's often the stigma that those women look after their children in a bad way, that they're not interested in their lives. (administration, FG10)

Additionally, in the field of non-formal education, the participants in the focus groups also pointed out other discriminatory situations experienced by children from a migrant background:

When I was a child, nobody wanted to take the migrant boys from my football team in their car. I mean, well, my dad didn't mind....In this case, one was called Mohamed and the other one Abdullatif, but nobody wanted to take them in their car, you know? Their families couldn't take them to the matches, and the other families didn't want to take care of them. It was like: "They are rubbish, you take them." (young person, FG5)

This final quote is a harsh example of the explicit racist situations experienced by these migrant children, in this case within a football team, which represent a clear obstacle to creating a sense of belonging.

\section{Conclusion}

In 2007, the Council of Europe called for societies to become more plural and democratic, a move that necessarily entails them becoming both pluricultural and multilingual. In line with this, the diversity management model proposed by the Regional Government of Catalonia $(2008,2017)$ has been defined as intercultural and claims to promote the construction of a common or shared public culture based on "mutual accommodation between the various cultural groups" (Regional Government of Catalonia, 2017, pp. 13-14). However, years on from its conception, we can see that policy efforts have been limited. In addition, research trends demonstrate that we still know little about the life experiences and collective perspectives of many citizens, such as young generations in Catalonia (see, for instance, Narciso, 2021), who are characterized more than ever by an unprecedented diversity of origins and experiences. The results of the present study contribute to identifying factors that clearly restrict the construction of this common public culture and a sense of belonging to the territory among all citizens.

Fieldwork has revealed that intercultural education, understood by some as the "conflict prevention device" (Leclercq, 2002) or the "coping strategy" (Batelaan, 2003) for learning to live harmoniously together, which has been used to promote democracy through a dialogue that seeks to avert conflict (Todd, 2011), has failed to achieve its aims. Results show that there are discrepancies between political discourses and official documents-which promote interculturality and mutual recognition of diversity based on a shared public culture-and what happens in practice, certain dynamics of discrimination having been constructed historically (see, e.g., Singh \& vom Hau, 2016) and still being constructed in everyday life. To adopt Ball's (1993) terminology, while policy as text points towards an intercultural model of diversity management, in practice, this model is conditioned and limited by exclusive discriminatory dynamics that permeate different social spheres and make such policy as text deviate from reality.

In particular, the results exposed above, which represent the main areas of consensus among participants from all the territories, point out diverse areas of discrimination, some of them involving the violation of civil and political rights (among others, obstacles to access to citizenship and the right to vote, difficulties in accessing the public function, recognition of academic qualifications and skills, submission to greater vigilance by the security forces). Others are linked to the violation of economic, social, and cultural rights (educational rights, greater difficulties in finding work, and obstacles to house access). A part of the explanatory factors of this reality has to do with the effects of the processes of exclusion or discrimination that manifest ethnic coordinates (mainly in access), including family origin, religion, language, etc. (Parella, 2016). Most of the study participants consider 
that all of these barriers, without exception, "complicate their belonging" to the Catalan territory and the real possibilities of truly achieving a pluricultural collective identity. There is a persistence of what some participants consider to be micro-racism, while others, without naming it explicitly, describe situations that reveal the difficulties they face in feeling identified with an environment that sends them messages of not belonging in their daily lives. This can be related to the effect of post-racial universalist approaches adopted by current European practices of interculturalism which might be falling short in the fight against discrimination since they are making it more difficult to challenge societal prejudices and structural racism (Lentin, 2020; Rodríguez-García, 2022).

Therefore, to achieve belonging and build a common public culture in which all of the people of Catalonia feel identified, as promoted by official speeches, it is essential to work to achieve effective equality of rights, duties, and opportunities from the point of view of equity and social justice. It is also necessary to recognize plurality and diversity and promote citizen participation in devising public actions, as well as encourage interactions, emphasizing all common and shared aspects (Pàmies et al., 2020). At a governance level, this is possible by addressing each of the five core critiques on which recent criticism on integration has focused: normativity; negative objectification of migrants as "other"; an outdated image of society; methodological nationalism; and a narrow focus on migrants in the factors shaping integration processes (Spencer \& Charsley, 2021). From the educational field, we believe that education can play a major role in doing this, since diversity is mobile and complex, and thus requires approaches that foster constructive multiculturalism to combine a flexible, mobile, and different idea of cultural identity with a claim for equity and social justice against discrimination and oppression (Torres \& Tarozzi, 2020).

The social dynamics that generate discrimination, such as those that have been explored throughout this article, must necessarily be redirected. In this respect, it should be noted that, although this research has identified dynamics and discriminatory discourses referring to different axes of oppression, the most prevalent boundaries to belonging that have been mentioned relate especially to racism, discrimination based on beliefs, and legal status. Thus, we must consider that discrimination and structural violence-such as racism, economic and social inequality, and the violation of rights, among othersrepresent clear obstacles to a sense of belonging and the construction of a common public culture. In this sense, research shows that the experiences of "everyday bordering" (Yuval-Davis et al., 2018) that affect large sectors of the population, but especially migrants and their children, can lead to the generation of reactive identities that further aggravate the risks of social exclusion. This article has specifically focused on all those areas of discrimination that limit and hinder the achievement of a shared public culture in Catalonia. In this sense, focus groups are well fitted for collecting data on this topic but they have been underused, especially in literature on belonging and identity. This approach is useful and necessary to further discourse analysis. Besides, actual participatory ethnographic research in this field is also indispensable for a deeper understanding of the intersecting experiences and effects of discrimination while exploring points of convergence and divergence to build a shared public culture. We also call for new scholarship that moves towards an intersectional analysis and thinking, to address and find responses to the areas that limit and hinder belonging and participation in contexts of diversity.

Undoubtedly, we are faced with a challenge that not only raises questions related to social integration but also questions the very policies of redistribution, recognition, and participation. This forces us to rethink the conditions offered to accommodate minorities, but also how their public recognition is made possible, how opportunities and a sense of belonging are made available to them, as well as how national citizenship is built. Equal rights and opportunities must be a social imperative that unites us all. We cannot remain blind to differences and inequalities and impassive to how individual and group alterities are constructed. As Moodod (2010) stated, we need a conception of equal citizenship, but also mechanisms to be able to address all forms of structural minority and daily exclusion, ending the spaces of impunity of certain groups that do not favour social cohesion, and also reviewing a regulatory framework that substantially discriminates against many people.

\section{Acknowledgments}

We would like to thank all the participants and members of the IDCOL project, and the reviewers for their insightful comments.

\section{Conflict of Interests}

The authors declare no conflict of interests.

\section{References}

Álvarez-Gálvez, J., Echavarren, J. M., \& Coller, X. (2018). Bound by blood: The ethnic and civic nature of collective identities in the Basque Country, Catalonia and Valencia. Nations and Nationalism, 24(2), 412-431. https://doi.org/10.1111/nana.12379

Anthias, F. (2009). Translocational belonging, identity and generation: Questions and problems in migration and ethnic studies. Finnish Journal of Ethnicity and Migration, 4, 6-15.

Ball, S. J. (1993). What is policy? Texts, trajectories and toolboxes. Discourse: Studies in the Cultural Politics of Education, 13(2), 10-17. https://doi.org/10.1080/ 0159630930130203

Ball, S. J., Maguire, M., \& Braun, A. (2012). How schools 
do policy: Policy enactments in secondary schools. Routledge. https://doi.org/10.4324/97802031531 85

Banks, J. A. (2007). Educating citizens in a multicultural society (2nd ed.). Teachers College Press.

Banks, J. A. (2008). Diversity, group identity, and citizenship education in a global age. Educational Researcher, 37(3), 129-139. https://doi.org/ $10.1177 / 002205741419400302$

Batelaan, P. (2003). Intercultural education in the 21st century: Learning to live together. Council of Europe Standing Conference of European Ministers of Education.

Benhabib, S. (2006). Democratic iterations: the local, the national, and the global. In S. Benhabib \& R. Post (Eds.), Another cosmopolitanism (pp. 45-74). Oxford University Press. https://doi.org/10.1093/ acprof:oso/9780195183221.003.0003

Bernat, I., \& Whyte, D. (2019). Postfascism in Spain: The struggle for Catalonia. Critical Sociology, 46(4/5), 761-776. https://doi.org/10.1177/0896920519867 132

Bernad, O., \& Llevot, N. (2018). La diversidad religiosa y cultural en la escuela pública de Cataluña [Religious and cultural diversity in Catalonia public school]. In J. J. Gázquez, M. del M. Molero, Á. Martos, M. del M. Simón, A. Belén, \& M. Sisto (Eds.), La convivencia escolar: Un acercamiento multidiciplinar [School communal living: A multidisciplinary approach] (Vol. 3, pp. 119-126). ASUNIVEP.

Braun, V., \& Clarke, V. (2006). Using thematic analysis in psychology. Qualitative Research in Psychology, 3, 77-101. https://doi.org/10.1191/1478088706qp $0630 a$

Burchianti, F., \& Zapata-Barrero, R. (2014). Is Catalonia immune to racism? An analysis of intolerant political discourses of mainstream party representatives (2010-2011). Journal of Immigrant \& Refugee Studies, 12, 401-417. https://doi.org/10.1080/15562948. 2014.932478

Byrne, S. (Ed.). (2021). Identity and nation in 21st century Catalonia: El procés. Cambridge Scholars Publishing.

Cabezas, M. (2022). Silencing feminism? Gender and the rise of the nationalist far right in Spain. Signs: Journal of Women in Culture and Society, 47(2). https:// doi.org/10.1086/716858

Carrasco, S., Pàmies, J., \& Ponferrada, M. (2011). Fronteras visibles y barreras ocultas: La experiencia escolar del alumnado marroquí en Cataluña y mexicano en California [Visible limits and hidden barriers: The school experience of Moroccan students in Catalonia and Mexican students in California]. Revista Migraciones, 29, 31-60.

del Griera, M. (2016). El mapa religiós i els nous imaginaris espirituals [The religious map and the new spiritual imaginaries]. In S. Giner (Ed.), La societat catalana al segle XXI [Catalan society in the 21st century] (pp. 377-396). Institut d'Estudis Catalans \&
Enciclopèdia Catalana.

El Mouali, F. (2021). Mares d'origen marroquí a Catalunya. Entre les experiències personals $i$ els processos d'acompanyament a l'escolarització dels fills i filles [Mothers of Moroccan origin in Catalonia. Between personal experiences and the processes of accompanying their children's schooling] [Unpublished doctoral dissertation]. Autonomous University of Barcelona.

European Commission. (2020). Communication from the Commission to the European Parliament, the Council, the European Economic and Social Committee and the Committee of the Regions. Action plan on integration and inclusion 2021-2027 (COM 758 Final). https://ec.europa.eu/migrant-integration/news/ the-ec-presents-its-eu-action-plan-on-integrationand-inclusion-2021-2027

Farinosi, M., Fortunati, L., O'Sullivan, J., \& Pagani, L. (2019). Enhancing classical methodological tools to foster participatory dimensions in local urban planning. Cities, 88, 235-242. https://doi.org/10.1016/ j.cities.2018.11.003

Gangahar, M. (2015). Locating the self between national and global. Al and Society, 30(2), 167-172. https:// doi.org/10.1007/s00146-013-0497-4

Garcés, B., \& Penninx, R. (2016). Integration processes and policies in Europe: Contexts, levels and actors. Springer.

Giesen, B., \& Seyfert, R. (2016). Collective identities, empty signifiers, and solvable secrets. European Journal of Social Theory, 19(1), 111-126. https://doi.org/ 10.1177/1368431015573364

Koopmans, R., Statham, P., Giugni, M., \& Passy, F. (2005). Contested citizenship: Immigration and cultural diversity in Europe. University of Minnesota Press.

Kymlicka, W. (1995). Multicultural citizenship: A liberal theory of minority rights. Oxford University Press.

Lapresta, C., \& Huguet, Á. (2008). A model of relationship between collective identity and language in pluricultural and plurilingual settings: Influence on intercultural relations. International Journal of Intercultural Relations, 32(3), 260-281. https://doi.org/10.1016/ j.ijintrel.2007.10.004

Leclercq, J. M. (2002). The lessons of thirty years of European co-operation for intercultural education. Council of Europe Steering Committee for Education.

Leiva, J. S. (2011). Participación de las familias inmigrantes y educación intercultural en la escuela [Participation of immigrant families and intercultural education in the school]. Contextos Educativos, 14, 119-133. https://doi.org/10.18172/con.643

Lentin, A. (2020). Why race still matters. Polity Press.

Martínez-Ariño, J., del Griera, M., García-Romeral, G., \& Forteza, M. (2011). Inmigración, diversidad religiosa y centros de culto en la ciudad de Barcelona [Immigration, religious diversity and worship centres in the city of Barcelona]. Migraciones, 30(30), 101-133.

Moodod, T. (2010). Still not easy being British: Struggles 
for a multicultural citizenship. Trentham Books.

Moodod, T. (2021a). National identity and ethnoreligious identity. Identities, 28(4), 506-512. https://doi.org/ 10.1080/1070289X.2020.1852794

Moodod, T. (2021b). The multiculturalist challenge: A rejoinder. Patterns of Prejudice, 55(2). https://doi. org/10.1080/0031322X.2020.1866880

Narciso, L. (2021). "Race," belonging and emancipation: Trajectories and views of the daughters of Western Africa in Spain. Social Sciences, 10(4). https://doi.org/ 10.3390/socsci10040143

Pàmies, J., Carrasco, S., Pinyol, G., Riera, N., Mesas, A., Sánchez-Martí, A., Narciso, L., Aoulad, M., Moya, D., el Mouali, F., Girós, R., García, J., Poblet, G., El Jabary, C., Llos, B., \& Caravaca, A. (2020). Vers una identitat col-lectiva pluricultural (IDCOL) [Towards a pluricultural collective identity (IDCOL)]. Autonomous University of Barcelona.

Parella, S. (2016). Immigració i ocupació a Catalunya: Urgències i principals reptes davant d'un horitzó de recuperació económica [Immigration and occupation in Catalonia: Pressing needs and main challenges before a horizon of economic recovery]. In G. Pinyol (Ed.), Informe sobre la integració de les persones immigrades a Catalunya 2015 [Report on the integration of immigrant people in Catalonia 2015]. Obra Social "La Caixa." http://treballiaferssocials.gencat. cat/ca/ambits_tematics/immigracio

Phillimore, J., Sigona, N., \& Tonkiss, K. (2020). Superdiversity, policy and governance in Europe. Multi-scalar perspectives. Policy Press. https://doi.org/10.1332/ policypress/9781447352051.001.0001

Pries, L. (2013). Ambiguities of global and transnational collective identities. Global Networks, 13(1), 22-40. https://doi.org/10.1111/j.1471-0374.2012.00368.x

Regional Government of Catalonia. (2008). Pacte nacional per a la immigració: Un pacte per viure junts $i$ juntes [National pact for Immigration: A pact for living together].

Regional Government of Catalonia. (2017). Pla de ciutadania $i$ de les migracions 2017-2020 [Citizenship and migrations plan 2017-2020].
Rodríguez-García, D. (2022). The persistence of racial constructs in Spain: Bringing race and colorblindness into the debate on interculturalism. Social Sciences, 11(1). https://doi.org/10.3390/socsci11010013

Rubio-Carbonero, G., \& Zapata-Barrero, R. (2017). Monitoring discriminatory political discourse on immigration: A pilot study in Catalonia. Discourse \& Society, 28(2), 204-225. https://doi.org/10.1177/ 0957926516685464

Shaimi, M. (2018, September 28). Catalunya intercultural? [Catalonia intercultural?]. Diari Ara. https:// www.ara.cat/opinio/mostafa-shaimi-catalunyaintercultural_0_2096790479.html

Singh, P., \& vom Hau, M. (2016). Ethnicity in time: Politics, history, and the relationship between ethnic diversity and public goods provision. Comparative Political Studies, 49(10), 1303-1340. https://doi.org/ 10.1177/0010414016633231

Spencer, S., \& Charsley, K. (2021). Reframing "integration": Acknowledging and addressing five core critiques. Comparative Migration Studies, 9, 1-22. https://doi.org/10.1186/s40878-021-00226-4

Todd, S. (2011). Educating beyond cultural diversity: Redrawing the boundaries of a democratic plurality. Studies in Philosophy and Education, 30(2), 101-111. https://doi.org/10.1007/s11217-010-9215-6

Torres, C. A., \& Tarozzi, M. (2020). Multiculturalism in the world system: Towards a social justice model of inter/multicultural education. Globalisation, Societies and Education, 18(1), 7-18. https://doi.org/ 10.1080/14767724.2019.1690729

Vertovec, S. (2007). Super-diversity and its implications. Ethnic and Racial Studies, 30(6), 1024-1054. https:// doi.org/10.1080/01419870701599465

Yuval-Davis, N. (2006). Belonging and the politics of belonging. Patterns of Prejudice, 40(3), 197-214. https://doi.org/10.1080/00313220600769331

Yuval-Davis, N., Wemyss, G., \& Cassidy, K. (2018). Everyday bordering, belonging and the reorientation of British immigration Legislation. Sociology, 52(2), 228-244. https://doi.org/10.1177/003803851 7702599

\section{About the Authors}

Angelina Sánchez-Martí holds a PhD in education and society and is currently a Serra Húnter Tenure-track lecturer in the Department of Applied Pedagogy, in the area of research on methods and diagnosis in education, at the Autonomous University of Barcelona. As a member of CER-Migracions, she has undertaken investigations mainly in the field of education and children of migrants.

Jordi Pàmies holds a PhD in social and cultural anthropology and is a full professor in the Department of Educational Theories and Social Pedagogy at the Autonomous University of Barcelona. He has been involved in research related to education, migration, and inequalities mainly on the socio-educational trajectories of young people of foreign origin. He is a member of CER-Migracions research group since its inception. 
Alejandro Caravaca is a PhD candidate in education at the Autonomous University of Barcelona. He holds a master's degree in social policy, work and welfare, and a bachelor's degree in educational studies from the UAB. He has participated in research projects about education policy in Central America and the Caribbean, the role of the World Bank in education policymaking, and gender perspective in Catalan education, among others. His main research interests are education policy, comparative and international education, and gender studies.

Berta Llos is a PhD candidate in education at the Autonomous University of Barcelona. She holds a master's degree in social policy, work and welfare, a bachelor's degree in educational studies, and a bachelor's degree in primary education, all from the UAB. She has participated in research projects about educational transitions and gender perspectives in education in Catalonia, among others. Her research interests are related to the sociology of education, education inequalities, and gender studies. 